\title{
Ecological and faunal analysis of dragonflies (Odonata) of suborders Zygoptera, Caloptera in Republic of Ingushetia
}

\author{
Fatima Tuganovna Tochieva, Tugan Yunusovich Tochiev* \\ Ingush State University, Magas, Russia.
}

\begin{abstract}
In this work, we adhere to the systematics proposed by the school of odonatologists B.F.Belyshev, that is, the order is subdivided into three suborders: Anizoptera, Zygoptera and Caloptera. In this article, we first characterize the suborders Zygoptera, Caloptera. The article provides a systematic composition and an overview of taxa common in the RI. [one]. On the basis of literature sources, brief characteristics of suborders, families and genera are given, and the problems of taxonomy and nomenclature of individual species and basic information on the distribution of taxa found in the study area are discussed. Analysis of the existing stream of literary information on dragonflies indicates that there are still problems, the solution of which requires close attention. First of all, this is the lack of research on the Caucasian regional odonatofaunas.
\end{abstract}

The Republic of Ingushetia is located in the southeastern part of the North Caucasus and stretches from 43035 'to $42045^{\prime}$ east longitude and from 45030 'to $45015^{\prime}$ ' north latitude. In the west, RI borders on the Republic of North - Ossetia (Alania), in the north and east the Chechen Republic, in the south - Georgia. The area of the republic is more than 3.6 thousand $\mathrm{km} 2$.

The surface of the republic has a complex relief, along with peaks reaching more than $4000 \mathrm{~m}$ asl, there are lowlands lying at an altitude of 200-300 m asl. There are 5 zones of vegetation: steppe, forest, mountain-xerophytic, subalpine and alpine.

Odonata is a unique order of the class of insects, the age of which dates back to several hundred million years. They are characterized by high morphophysiological specialization, due to which they are elevated to a separate infraclass.

We set a goal - to study taxonomic diversity, ecological - geographical features and adaptive strategies for the altitudinal-belt distribution of the RI dragonflies.

To achieve the goal the work, the following task was set: to study in detail the dragonfly fauna of the Republic of Ingushetia.

\footnotetext{
* Corresponding author: tochiev.tugan@mail.ru
} 


\section{Materials and methods}

In this work, we adhere to the systematics proposed by the school of odonatologists B.F.Belyshev, that is, the order is subdivided into three suborders: Anizoptera, Zygoptera and Caloptera. In the course of our research, we have established for the first time that on the territory of the Republic of Ingushetia, the odonatofauna includes two suborders, uniting 4 families, 6 genera, and 18 species. [1,2]. We provide a systematic composition and an overview of taxa common in the RI. On the basis of literature sources, brief characteristics of suborders, families and genera are given, and the problems of taxonomy and nomenclature of individual species and basic information on the distribution of taxa found in the study area are discussed.

The method of collecting dragonflies, in general, does not differ from the generally accepted method of collecting insects that spend a significant part of their time in the air and in vegetation, but there are specific features that we also took into account.

When collecting the material, we used air nets and all the main methods usable in entomological practice. Collecting flying insects: when an insect is found, they approach imperceptibly and with a sharp wave, the net is hooked. On the fly, the net is turned over 180 degrees, and the insect will be in the net bag and can be easily removed from it. The insect can be caught in the net with your hands or selected with an exhauster and then placed in a stain.

\section{Results}

\subsection{ZYGOPTERA}

A suborder of medium-sized dragonflies. There are 33 families, 122 genera and more than 1000 species in the world fauna.

For the first time in RI, a suborder is represented by 3 families, including 5 genera and 16 species [3]

\section{Family Platycnemididae}

Ethiopian-oriental family, includes 24 genera.

We found 2 species of the same genus in the odonatofauna of the Republic of Ingushetia.

Genus Platycnemis

Tropical genus, includes 33 species.

We found two species of the genus in the RI.

\section{P. dealbata}

\section{Spread}

Near Asian species, inhabits the Eastern Mediterranean.

Found in Transcaucasia and in the east of the North Caucasus [4].

Distributed in the Republic of Ingushetia in the eurygypsum zone within 450-900m. The species is common in numbers.

\section{P. pennipes}

\section{Spread.}

Trans-Eurasian, a widespread species from the genus that inhabits all of Europe. Common and numerous throughout the Caucasus, including the Republic of Ingushetia.

On the territory of the Republic of Ingushetia, individuals of the species were registered in the eurygypsum zone (450-900m.).

The species is part of the core of the odonato complex.

\section{Family Coenagrionidae}

One of the largest families in the suborder Zygoptera, numbering 85 genera and over 600 
species.

The RI contains 11 species, which are included in 3 genera.

Genus Coenagrion

The type genus of the family, including itself 36 species, distributed exclusively in Eurasia [4]. In the study area, we count 5 species.

\section{C. scitulum}

\section{Spread.}

The range of the species is Mediterranean-Central Asian, which is highly fragmented into foci. According to V. Schneider [5] C. scitulum is numerous in Syria, Lebanon, Jordan. For the Near Asian part of the range, A.N. Bartenev [7], one male leads for the territory, the habitat of the analyzed species. Some odonatologists refer to this information and cite the species in the list of Iranian dragonflies [6].

The analyzed species in the study area is found exclusively on the plain within the range of $26-450 \mathrm{~m}$.

\section{C.puella}

Spread.

European-Mediterranean-West Palaearctic species, has a vast range. Distributed from northern Africa to Scandinavia. In the Asian part, the area is narrowed and limited to the northern foothills of the Tien Shan, [7].

On the territory of the study, it is a rare species, widespread in the eurygypsum zone (450$900 \mathrm{~m}$.).

\section{C.vernale}

\section{Spread.}

Boreo-montane trans-Eurasian species, widespread in the mountains [4]. In 2006, the species was found on the northern slopes of the Dzhungarskiy Alatau [10].

On the territory of the Republic of Ingushetia, the taxon lives exclusively in the mountains, over $900 \mathrm{~m}$. Occurs locally.

\section{C. armatum}

\section{Spread.}

Has a trans-Eurasian area. The species penetrates into the Mediterranean zoogeographic subregion only in the Caucasus, where the taxon is found locally [4]. This taxon is typical for dragonflies in Kyrgyzstan [11]. The species is also given for Central Asia [12].

In the area of the RI study, the species is confined exclusively to the mountains. Occurs locally within 900 meters or more above sea level. Rare.

\section{C. Ornatum}

\section{Spread.}

Eastern Mediterranean species of the genus, has a continuous range from Iraq to the Balkans, southern France, southern Turkmenistan [13]. In Central Asia, the taxon is known from single finds in Turkmenistan [13].

On the territory of the RI study, the taxon is a small species strictly confined to the plain (150-450 m.).

\section{Genus Erytromma}

Genus, has 2 species taxa. Some odonatologists include the species E. humerale in this genus [10], while others consider the status of this taxon to be overestimated $[4,14]$. One of the species of the genus lives on the territory of RI.

\section{E. Viridulum}

\section{Spread.}

A Mediterranean species of the genus, the range of which fits perfectly into the boundaries of the Mediterranean zoogeographic subregion [4]. The genus Erytromma is recognized as Mediterranean because both species are closely related to the region. According to Kh.A. Ketenchiev and A.Yu. Kharitonov [3-5], E. viridulum is endemic for this unit and is located 
in the place of its formation.

For the study area, the species is common in numbers, strictly confined to the flat part (50$450 \mathrm{~m}$.) Of the republic.

\section{Family Lestidae}

The family includes 13 genera. It is generally accepted that in boreal Eurasia there are two genera [5], including 10 species. Six of them are present on the territory of the Republic of Ingushetia.

\section{Genus Lestes}

Worldwide widespread genus, numbering about 120 species. We have identified 6 species on the territory of the Republic of Ingushetia.

\section{Ldryas \\ Spread.}

Circumboreal, Holarctic boreo-montane species. In the Eurasian part of the range, it is noted from the Arctic Circle to Africa and Afghanistan [5]. Inhabits the entire Mediterranean zoogeographic subregion. In the south, the species occurs locally [4].

On the territory of the Republic of Ingushetia, the species is mainly eryhypsum, although it is also found on the plain.

\section{L.sponsa}

\section{Spread.}

Trans-Eurasian species. It has a similar habitat with the previous species. In the west, it occurs from the Arctic Circle to North Africa [15], and in the south of Japan it penetrates into the Oriental Zoogeographic Region [16]

In the study area, the species is mostly eurygypsum, the distribution limits of which range from 450 to $900 \mathrm{~m}$.

\section{L.virens}

\section{Spread.}

Mediterranean-West Asian species, penetrates North Africa, distributed up to Altai [9]. In the northern part of Europe, it is found in Scandinavia [15]. The southernmost point of distribution is northeastern Afghanistan.

On the territory of the study, the species is common in number, strictly confined to the plain (50-450 m.).

\section{L. barbarus}

\section{Spread.}

The Mediterranean-West Asian species, widespread in the east, is found in Altai and Mongolia. In Europe, recorded off the coast of the North and Baltic Seas. The taxon is common in the vicinity of Almaty and Frunze; these are the southernmost localities of the species [10].

The species, on the territory of the republic, is confined to the mountains (900-2744 m.), Can penetrate slightly into adjacent territories. Has the usual strength.

\section{L. macrostigma}

\section{Spread.}

Mediterranean-West Asian species, the range of which lies in the south of Europe, in Asia Minor and Central $[9,15]$. Locations in Israel are known [6]. The distribution of the species is characterized by locality and aperiodic fluctuations in numbers [10,15]. In Central Asia, the species is recorded in the northern plains of the region and in the foothills of the Kopetdag [10]. The species is characterized by local distribution and fragmentation of the area [4]

On the territory of the Republic of Ingushetia it is a typical plain species, where it is found locally. The number is insignificant.

\section{L.viridis}

Spread. 
Endemic to the Mediterranean zoogeographic subregion [14].

On the territory of the Republic of Ingushetia it is considered an eurygypsum species, it is found at altitudes from 450 to $900 \mathrm{~m}$., Is not numerous.

\section{Genus Sympecma}

On the taxonomy of this kind, there is a huge number of different judgments $[9,10,17,18]$.

The correct solution of systematic problems is reflected in the works of S.N.Borisov (1987) and A.Yu. Kharitonov (1991), as a result of which it can be seen that the genus Sympecma contains three species, which are characterized by clinal variability. We registered two species in the study area. [5,15]

\section{S. fusca}

\section{Spread.}

South Eurasian species, which is characterized by a trans-Eurasian range. The entire territory of the Mediterranean zoogeographic subregion is densely populated, but to the east, the area is fragmented to point, strongly separated foci, which in turn suggests that the Mediterranean zoogeographic subregion is the optimum habitat for the species and the center of its origin [4].

On the territory of the Republic of Ingushetia, an ubiquitous mountain (900-2744 m.) Species, which can penetrate into the flat part of the study area, is ubiquitous.

\section{S. paedisca}

\section{Spread.}

Transeurasian. South Eurasian species, range, which extends from Japan to the Baltic and Black Sea region [14]. In the west, it is found in the Netherlands and Eastern Switzerland [15]. Common in the Caucasus and the Armenian Highlands [4]. Individuals of the species are found in the Northern Tien Shan [13]. On the territory of the Republic of Ingushetia, the species is strictly confined to the plain $(30-450 \mathrm{~m}$.). The number of the species is insignificant

\subsection{CALOPTERA}

On the territory of the Republic of Ingushetia, the suborder is first represented by 1 family, which includes 1 genus with two species.

\section{Family Calopterygidae}

A tropical family of 16 genera. In the Mediterranean zoogeographic subregion and in the Caucasus, there is a single genus Calopteryx [14] with a very complex and unsettled taxonomy, which has been revised many times [17]. The generic taxon includes about 20 species. There are 2 species of the genus inhabiting the territory of the Republic of Ingushetia.

\section{Genus Calopteryx}

\section{C. virgo.}

\section{Spread.}

European-West Asian species. Before the publication of the article by E.I. Malikova (1995), it was believed that the species had a trans-Eurasian distribution. However, it turned out that this is not legitimate, since in some eastern parts of the range, C. virgo was considered a species of $\mathrm{C}$. japonica. It is believed that $\mathrm{C}$. virgo inhabits almost the entire Mediterranean zoogeographic subregion.

Eurygypsum (450-900m.), A common species inhabiting the territory of the Republic of Ingushetia.

\section{S. splendens}

Spread.

A trans-Eurasian species that inhabits the entire Mediterranean zoogeographic subregion [17]. 
In the Republic of Ingushetia, the species is distributed in the eurygypsum zone within 450$900 \mathrm{~m}$. In terms of numbers, it is a common species.

\section{Findings}

On the basis of field research and analysis of collection materials, the composition of the dragonfly fauna of RI was established, including the suborders Zygoptera Caloptera. In RI, suborders are represented by 4 families, including 6 genera and 18 species.

\section{References}

1. F.T. Tochieva, M.R. Vyshegurova, L.G. Arapieva, Materials of the XXII International Scientific Conference Grozny, 375-378 (2020)

2. F.T. Tochieva, M.R. Vyshegurova, Materials of the XXII International Scientific Conference Grozny, 382-388. (2020)

3. Kh.A. Ketenchiev, L.Sh. Amkhaeva, Scientific-theoretical journal "Izvestia" of the Gorsk State Agrarian University, 50- 2, 330-338. (2013).

4. Ketenchiev Kh.A. Dragonflies of the Mediterranean: author. dis. ... doct. biol. Sciences (Makhachkala, 2002)

5. B.F. Belyshev, A.Yu. Kharitonov, Geography of dragonflies (Odonata) of the Boreal faunal kingdom. (Science, Novosibirsk, 1981)

6. Schneider W. Systematik und Zoogeographie der Odonata der Levante unter besonderer Beriicksichtigung der Zygoptera (Diss. Univ. Mainz, 1986).

7. A.N. Bartenef, Russian. ent. review 16(3-4), 343-345 (1912)

8. H. Heidari, H. J. Dumont, Zoology in Middle East, 26, 133-150, (2002).

9. B.F.Belyshev, A.Yu. Kharitonov, Zool. zhurn., 54(3), 471- 472. (1973).

10. S.N. Borisov Dragonflies (Insecta, Odonata) of Central Asia and their adaptive strategies: dis. ... doct. biol. Sciences (Novosibirsk 2007)

11. V.N.Krylova, Dragonflies of Kyrgyzstan: author. dis. ... Cand. biol. Sciences (Frunze 1969)

12. A.N. Popova, Tr. Zool. Institute of the USSR Academy of Sciences. 9, 861-894. (1951)

13. B.F. Belyshev., A.Yu. Kharitonov, S.N. Borisov Fauna and Ecology (Science, Novosibirsk, 1989).

14. L.Sh Amkhaeva., Kh.A KetenchievScientific-theoretical journal "Izvestia" of the Gorsk State Agrarian University. 51(2) (1999)

15. R.Jodicke, Die Binsenjungfern und Winterlibellen Europas: Lestidae (DieNeue BrehmBucherei; Magdeburg ,. 1997)

64. T.Ueda T. Geographic variation in the life cycle of Lestes spousal '. Tombo. -. 21. 2734 (1978).

17. A.N. Bartenev A note about dragonflies in the vicinity of Signagh (Tiflis, 1916)

18. Z.D. Spuris, Order Odonatoptera (Odonata) - Dragonflies. Keys to insects of the European part of the USSR. -. -T. 1, 137-161 (1964) 